\title{
Human Resource Management and Diversity Management. Some Emerging Evidence about the Effects on Organizational Performance
}

\author{
Vittorio Corsi ${ }^{1}$
}

\begin{abstract}
The study aims to analyse the role assumed by diversity in organization and its dynamics consequences for the Human Resource Management. In this regard, a focus on gender diversity and is effect on organizational performance is empirically investigated.

The literature on International Human Resource Management has constantly dealt with, both from a theoretical and managerial perspectives, the opportunities for enterprises to gain from the emergent diversity in organization, improving their performance.

Based on a sample of 636 Italian firms over the period 2010-2020, the findings show that gender diversity - as critical element of the diversity management significantly influences the firm performance measured by firm innovation.
\end{abstract}

JEL classification numbers: $\mathrm{O} 30, \mathrm{O} 32$.

Keywords: Human Resource Management, Diversity management, Gender diversity, Firm performance, Italy.

${ }^{1}$ University "G. d'Annunzio", Psychology Faculty, Chieti-Pescara. Italy.

Article Info: Received: December 23, 2021. Revised: January 15, 2022.

Published online: January 24, 2022. 


\section{Introduction}

The study aims to analyse the role assumed by diversity in organization and its dynamics consequences for the Human Resource Management. In this regard, a focus on gender diversity and is effect on organizational performance is empirically investigated.

For over twenty years, the literature on International Human Resource Management has consistently dealt with, both from a theoretical point of view and managerial practice, the opportunities for companies to enhance and profit from the growing diversity, above all the workforce, present in organizations (Bonache and Festing, 2020; Aswathappa ad Dash, 2020). At the basis of diversity, the main drivers analyzed are age, gender, religion, race, professional background. Above all, gender and race / ethnicity were in the past the main objects of observation, today the range of diversities is wider, starting to consider the other dimensions. Although in a situation of deep evolution, the concept remains strongly anchored to the theme of equal opportunities and the analysis of the main practices, increasingly rich and inclusive, does not go beyond the concept of diversity as a deviation from higher operating standards (inspired by the widespread management approach as a universal discipline). In substance, the prevailing logics, especially in large companies, are those of "protecting" and favouring a universalistic management of human resources and corporate practices revolve around this premise; obviously the concept evolves, the persistence of the phenomenon at the organizational level is increasingly rooted and increases the perception and growing awareness that the enhancement of diversity is an area of efficiency and effectiveness to be pursued over time (Meena and Vanka, S2017).

The adoption of Diversity Management practices (henceforth DM) in companies over the years has generated benefits on various fronts (Serio, 2014; Yadav and Lenka, 2020). In this regard, a convergence emerges in the literature that highlights positive effects regarding: a) the reduction in absenteeism rates; b) containment of costs resulting from staff turnover; c) the attraction and maintenance of talents; c) the creation of a work environment conducive to the enhancement of individual talent, motivation, and work-life balance.

In a nutshell, we are in the presence of actions aimed at the advanced management of human resources, however still read in a reactive key, and not linked to business strategies. In the prevalence of the practices observed, the business has not inherent the concept of diversity in its main drivers, although the need to govern processes is constant and growing due to a progressive increase in internal and external heterogeneity (Scroggins and Benson, 2010; Sukalova and Ceniga, 2020).

The DM presents itself as a practice widely existing among large multinational companies. Referring to Bartlett and Ghoshal's analysis of organizational models in the global world (Bartlett and Ghoshal, 2017), all practices tend to incorporate indications from the top which are then readapted with different margins of discretion in local contexts. The indications are generally codified explicitly, there is a very strong recourse to the adoption of ethical codes that in some way 
circumscribe the field of action, normalize it with respect to the different contexts of reference and trace the set of characterizing practices (Mullins, 2018). On the one hand, internal processes are activated aimed at "considering and enhancing one's own multi-ethnic component" as a factor of competitive advantage, on the other external processes "aimed at enhancing the multi-ethnic component" as a source of understanding of a global market with increasingly blurred borders.

From a theoretical point of view, the MD is located within the evolutionary approach to the management of human resources which considers the Human Resource not one, but "the" fundamental variable for the activation of the relationship between the company and environment and for the development of the organization (Boldizzoni, 2009). The environment is no longer an independent variable that conditions the organization; the relationship between business and the environment is more complex and is not seen in terms of adaptation or reaction, but of proactivity. The approach differs from the "linear" one, which assumes that the environment is relatively stable and predictable, and from the "interdependent" one, which identifies the ability to react and adapt organization is the key to managing environmental instability (Dennissen et al., 2020).

Within this theoretical framework, some experiences can be read that can be obtained from the broad and convergent review of practices present in organized contexts.

\section{Theoretical background}

\subsection{Diversity Management and business strategies}

Sections DM practices generally act as a facilitator, as an element of mediation and accompaniment to accelerate the adaptation of human resource management systems within companies in a changing world.

These are structured policies, generally of a sequential nature, entrusted and managed by "incardinated" roles within the large family of Corporate Social Responsibility (CSR). They are the result, in most cases, of a "stretching" of policies that facilitate personalized, more advanced, and more inclusive management of human resources. However, these are not widespread skills, but limited to the person, role and corporate function that oversees the file. The "natural" location within the CSR area tends to favour its communicative potential (Starostka-Patyk et al., 2015). As far as the individual sphere is concerned, the practices of DM, in their most varied manifestations, intersect the management of human resources in their entire development cycle. It is interesting that practices developed in diversity management contexts are then also transferred in a significant way to the whole organization; the concept of "inclusiveness", which inspires most of the practices, in fact activates virtuous paths that are not confined to diversity to be protected or enhanced but become the common heritage of the entire organization (Ashikali and Groeneveld, 2015; Ollapally and Bhatnagar, 2009).

From an organizational point of view, other elements are added. The pressures of a global market with increasingly blurred borders place the issue of international 
competitiveness on the agenda of the strategic agenda for the company and a significant part of the business is now developing in an international dimension. The internationalization process is much more than a search for a single market but concerns organizational structures, governance dimensions, relations with other companies in the various supply chains; in some way it becomes paradigmatic of a new way of being for the company. The analysis in question starts from the markets, but social changes place increasingly blurred boundaries in the individual / organization relationship and open organizational learning perspectives of undoubted interest (Argote, 2011).

A first sphere, as emerges from the cases and from the prevailing literature, concerns the area of human resource management. The DM naturally activates an individual or in any case micro-clustered treatment of the employees. And it is also clearly deducible from the set of practices that a large part of its effects and, in substance, of its starting assumptions are related to enhancing human resources and bringing the talent possessed internally by the company back to the centre of value creation (Cooke and Saini, 2010).

The objective of being able to develop policies that go beyond the logic of managerial "cosmetics" and "organizational luxury", that is confined to a prevalent aspect, is always current of enunciation, bringing back priorities and new evidence to the fact that "in a company that takes care of it you are better and above all you perform better". From this point of view, like other organizational practices and "fashions", the DM can become an interesting joke to promote initiatives that the tension towards efficiency of the last times seemed to have overshadowed the world of companies. The fact that there is a close link between company performance and enhancement practices is a consolidated awareness, although never fully "quantified" (Sabharwal, 2014). In this sense, some measurement indicators could be of greater help in the dissemination of tools, on a par with different issues, but of similar breadth, such as corporate welfare or the generation mix.

A second sphere concerns the positive effects on marketing and customer management policies. Positive company impacts are found in a business key, if the management of diversity is seen as a lever to manage different and distant markets, with different consumption habits. It is customary to use personnel who are culturally close to the reference markets, for language affinity, understanding of manners and consumption. The DM process is activated only when the interventions leave the specific commercial tactic, that of making the commercial transaction more feasible and become organizational assets (Sun et al., 2020; Torres and Murray, 2001).

For some time, in fact, even in small companies, internships, internships and so on have been widely used to try to recruit and then personalize the resource, which acts more as a mediator between two diversities. Also in this case, the DM acts as a picklock for a broader change by the company. The hybridization of the workforce imposed by the increasingly global market brings not only practices of managing diversity, but also and above all the culture of diversity that allows the company to have a mindset and a global vision, a necessary condition to compete and survive in 
the renewed international competition. Recent research would seem to confirm the fact that customers in accelerated growth markets (China, India, Russia, and Brazil) have better understood the role of the prosumer, that is, customer involvement in product development processes (Svendsen et al., 2011; Anning-Dorson, 2019). More and more "different" communities contribute and will contribute to product development, creating cultural symmetries that were unthinkable today between countries with a "western" economy and accelerated growth market areas.

A third area of analysis concerns innovation. Ideas emerge that confirm the creation of an environment conducive to diversity essentially translates into the construction of workshops for comparison and exchange in which different cultural perspectives hybridize and feed new business models. The topic is widely debated in the literature and is located within the paradigm shift imposed by the transition from "closed innovation" to "open innovation" (Bogers et al., 2018; Frey et al., 2011).

The close innovation logic is based on the idea of maintaining the competitive advantage through the emphasis on barriers to entry, both of an organizational nature, through the importance of the Research and Development function, and of a financial nature, through investments in these activities and the protection of intellectual property. The picture briefly described revolves around the themes of control, the "hierarchical" perspective of development and is divided into characteristics of size, influence strategy and enhancement of internal human capital. To borrow the perspective in a diversity key, a process of profound closure in which the actions are mainly suited to bringing different thoughts within the company back to a common logic (Belderbos et al., 2020; Sastre, 2015).

The open model, on the other hand, consists of a system in which cooperation and links between different actors generate innovative inputs useful for the market. In other words, open innovation involves the fact that networks of organizations, public and private, act together to innovate; the creation of value is not the exclusive result of an internal transformation of input into output - as the traditional innovation model indicates - but rather the intelligent and effective combination of internal and external resources. In this context, a similar interpretation can be superimposed on the ideal system that the most recent reflections on DM promote (Barrena-Martíne et al., 2020; Söllner, 2010).

In a logic of continuum between an open and closed system, even DM policies could favor interesting paths for the company. The intensification of structured interaction relationships with customers, suppliers, and industrial partners and, above all in perspective, the growth of collaboration relationships with universities and external research centres at an international level would seem to lead companies towards models less timid openings and less centre of gravity on the enhancement of internal resources, in line with the main successful experiences and practices present in international contexts. In this context, great benefit should be generated from the integration of selection and insertion practices, in which the local stakeholder system has already been activated and brought to a value factor. Connecting the DM processes to the primary processes of value creation in innovation helps to generate a more open context, more in line with competitive pressures and to favor the 
change of mindset at the basis of the interpretations proposed so far on the subject (Jolanta, 2015; Tatli, 2011).

A further sphere concerns the more general theme of corporate reputation. There is a direct correlation between DM practices and corporate reputation in the surrounding environment. The nature and system of relationships that the practice of DM activates facilitate the construction and visibility of the company within its reference cluster. Inclusion in the cluster is based on competence and reliability, a mix of technical skills and relationships in which technology, human capital and social capital are mixed. Globally, the transposition of these systems and their translation into intangible assets contribute to building the main source of competitive advantage and positioning in the global market; a positioning based on integration into multicultural systems, mediated by technical knowledge and by belonging to specific professional communities thanks to the reputation achieved over time. This determines an environment that is structurally built on diversity, from which it draws food and resources for competition, a heritage of trust shared with relevant stakeholders in the context who exchange resources and build identity (Ashikali and Groeneveld, 2015; Yang and Konrad, 2011).

The indicated drivers are convergent and integrated and generate a continuous exchange mechanism, each of the above factors confers and takes on the characteristics of the other. Factors move and feed themselves in a global context and increasingly put business models at the top of their priorities that position the company in inter-connected global systems, in which to operate through new organizational artifacts that make openness, comparison and exchange are the enabling factors in value creation processes. The new DM practices come out of the exclusive domain of CSR and Human Resource and are connected in a stable manner to competitive strategy processes, they are less and less used to normalize consolidated situations, more and more oriented to favour the understanding of a market, economic and social, increasingly diverse, and complex (Karataş-Özkan et al., 2014; Jamali and Dirani, 2014).

\subsection{A case of diversity management: gander diversity and organizational performance}

Women's work is not just a question of rights but is an element of growth and development, so the presence of women at the top is not only an element of equality but represents a value for organizations. Recent studies emphasize that heterogeneity or diversity is an ingredient of business success (Zimmerman and Brouthers, 2012). Having both men and women at the top of an organization can positively affect various corporate performance measures. In a heterogeneous context, in fact, the chances of facing choices with broader and more articulated perspectives increase, the audience of talents widens, a beneficial competition is triggered, leadership styles emerge that can be successful: it is proven that women are particularly capable of communicating, managing relationships, preventing conflicts, sharing decisions and, often, also facing risk with greater caution 
(Teodósio et al., 2021; Li and Chen, 2018).

The positive relationship between the presence of women and company performance has however for years been an unconsolidated result in the economic literature: some studies find a positive relationship (Smith et al., 2006), others a negative relationship (Adams et al., 2010), others they still find no effect of female presence on performance (Rose, 2007).

Matsa and Miller (2013) show that the presence of women on board of directors increases the likelihood that women will reach top management positions, including the position of CEO. This spillover effect is also highlighted by Wang and Kelan (2013). Matsa and Miller (2013) also show that the introduction of gender representation quotas in Norwegian listed companies has changed the style of leadership, for example it has reduced layoffs. By studying a sample of Italian family businesses, Amore et al. (2014) show that the joint presence of women in the positions of chief executive officer and board member significantly increases the company's performance.

Among other, Adams and Ragunathan (2017), focusing on US banks, find that those with more diversified CDAs by gender performed better during the recent economic crisis (the so-called "Lehman Sisters" hypothesis) because in the period of crisis, women implement risk monitoring and attention behaviours, which can have a positive impact on performance, on more occasions than men do.

Another important element of the relationship between gender diversity and corporate performance underlined by recent studies is the role of the mass of criticism. A study by Schwartz-Ziv (2012) uses original data from meeting minutes of approximately 402 board of directors and committees from a select sample of Israeli companies to show that companies with at least three female directors performed better (measured by from the ROE) of those without women. These companies also experienced greater turnover in top management when performance was not adequate. The presence of a critical mass of at least three women has resulted in increased board activism, both men and women.

\section{Method}

\subsection{Sample and Data}

With the purpose to analytically test the research proposal, the diversity management has been investigated with the empirical analysis of a sample of Italian university start-ups. In detail, a sample of 636 Italian firms, in the 2011 to 2020, has been analysed. Data was collected from AIDA database containing financial data of Italian companies.

\subsection{Variables}

\subsubsection{Dependent variable}

As dependent variable, it has been used a measure of firm performance in the form of firm innovation., measured by a dummy variable that takes the value 1 if the USO had any patent activity and 0 otherwise (Firm innovation). 


\subsubsection{Independent variables}

This study evaluates gender diversity in board (Gender diversity) by the share of the number of women on the total number of directors and its square (Gender diversity2) with the aim to detect potential non-linear relations.

\subsubsection{Independent variables}

Regarding the analytical approach, a regression model was used.

Fully, the following firm innovation functions was outlined, allowing for time and firm fixed effects:

Firm innovation $_{i t}=\beta_{1}$ Gender diversity $_{i t}+\beta_{1}$ Gender diversity $_{i t}{ }_{i t}+\beta_{2}$ Control variables $_{i t}+\varepsilon_{i t}$

\section{Main Results}

\subsection{Descriptive results}

Table 1 reports the descriptive statistics estimated on the variables used in the study. The results show a mean of 0.11 patents for each sampled firm, remarking the low capacity of the sample to innovate.

About the share of female directors on the board, the results show a sample mean of about $8 \%$, revealing the low gender diversity and the limited representation of women in board of the sampled firms.

Regarding to the share of foreign directors in board, the results report a sample mean of about $4 \%$, highlighting the low nationality diversity and, consequently, that foreign members have a scare participation in the board of the sampled firms.

Table 1: Descriptive statistics

\begin{tabular}{|c|c|c|c|c|c|}
\hline Variable & N. of firms & Mean & S.D. & Min. & Max. \\
\hline Firm innovation & 636 & 0.1105 & 0.2254 & 0 & 9 \\
\hline Gender diversity & 636 & 0.0814 & 0.3064 & 0 & 1 \\
\hline Age & 636 & 15.8956 & 3.4603 & 4 & 20 \\
\hline Size & 636 & 13.8583 & 1.4045 & 2.2134 & 15.6653 \\
\hline Economic index & 636 & 3.6745 & 11.0366 & -35.9000 & 31.9894 \\
\hline Innovative context & 636 & 0.3567 & 0.4205 & 0 & 1 \\
\hline Investors & 636 & 0.0034 & 0.0345 & 0 & 1 \\
\hline
\end{tabular}




\subsection{Estimation of the regression model}

Table 2 shows the findings of estimated regression. In detail, the results about the impact of the gender diversity on the firm innovation of the sampled firms show that the statistic on the variable Gender diversity is negative and statistically significant [column (ii): coefficient $=-5.0658, \mathrm{p}<0.05$ ]. Further, the statistic on the square of the Gender diversity is positive and statistically significant [column (ii): coefficient $=5.0437, \mathrm{p}<0.05]$.

These emerging results reveal that the association among gender diversity in board and firm innovation has a nonlinear form, with a relevant representation of women in board, gender diversity is associated with noteworthy innovative activities of the samples firms, while in the case of few women in board, gender diversity is associated with a negative impact on innovative activities of the sampled firms.

Table 2: Estimation of the regression model analysing that effect of gender diversity

\begin{tabular}{|c|c|c|}
\hline & Equation 1 & Equation 2 \\
\hline & (i) & (ii) \\
\hline Gender diversity & & $\begin{array}{c}-5.0658^{* *} \\
(1.0350)\end{array}$ \\
\hline Gender diversity $^{2}$ & & $\begin{array}{c}5.0437 * * \\
(1.0082)\end{array}$ \\
\hline \multicolumn{3}{|c|}{ Control variables } \\
\hline Age & $\begin{array}{c}0.5848 * * \\
(0.1435) \\
\end{array}$ & $\begin{array}{c}0.3551 * * \\
(0.0526)\end{array}$ \\
\hline Size & $\begin{array}{c}0.1634 * * \\
(0.0423)\end{array}$ & $\begin{array}{l}0.0725^{*} \\
(0.0425)\end{array}$ \\
\hline Economic index & $\begin{array}{l}-0.0134 * \\
(0.0234)\end{array}$ & $\begin{array}{c}-0.0104 * * \\
(0.0053)\end{array}$ \\
\hline Innovative context & $\begin{array}{c}0.4534 \\
(0.2335)\end{array}$ & $\begin{array}{c}0.2087 \\
(0.2853)\end{array}$ \\
\hline Investors & $\begin{array}{l}0.75823 \\
(0.4235)\end{array}$ & $\begin{array}{c}0.2039 \\
(0.6293)\end{array}$ \\
\hline
\end{tabular}

Note: The robust standard errors are reported in parentheses.

$* \mathrm{p}<0,10$.

$* * \mathrm{p}<0,05$.

$* * * \mathrm{p}<0,001$. 


\section{Conclusions}

The study aimed to analyse the role of diversity management in Human Resource Management, with an empirical focus on the role of gender diversity on board of directors on the firm performance (measured in term of firm innovation). Precisely, according with the theoretical framework outlined, it emerges that the association between gender diversity shows a non-linear connection with the innovation of the analysed firms. Indeed, the emerging association seems to assume a U-shaped form concerning to gender diversity.

The study postulates some theoretical contributions and implications. In detail, the research work adds new insights to the literature of diversity management in Human Resource Management by including novel contribution about the role of gender diversity on firm performance, with particular regard to the emerging innovative performance and consequences. The results add further proof on the Human Resource Management of gender diversity/firm outcomes relationship, developing new evidence about the curvilinear effect of gender diversity on the organizational performance.

\section{References}

[1] Adams, R. B. and Ragunathan, V. (2017). "Lehman sisters", Available at SSRN 3046451, 2017.

[2] Adams, R. B., Hermalin, B. E. and Weisbach, M. S. (2010). "The role of boards of directors in corporate governance: A conceptual framework and survey", Journal of economic literature, vol. 48, no. 1, 2010, pp. 58-107.

[3] Amore, M. D., Garofalo, O. and Minichilli, A. (2014). "Gender interactions within the family firm”, Management Science, vol. 60, no. 5, 2014, pp. 10831097.

[4] Anning-Dorson, T. (2019). "Complementarity of capabilities across cultures: Innovation, customer involvement, and competitiveness of service firms across India and the UK", Cross Cultural \& Strategic Management, 2019.

[5] Argote, L. (2011). "Organizational learning research: Past, present and future", Management learning, vol. 42, no. 4, 2011, pp. 439-446.

[6] Ashikali, T. and Groeneveld, S. (2015). "Diversity management for all? An empirical analysis of diversity management outcomes across groups", Personnel Review, 2015.

[7] Ashikali, T. and Groeneveld, S. (2015). "Diversity management in public organizations and its effect on employees' affective commitment: The role of transformational leadership and the inclusiveness of the organizational culture", Review of Public Personnel Administration, vol. 35, no. 2, 2015, pp. 146-168.

[8] Aswathappa, K. and Dash, S. (2020). "International Human Resource Management", McGraw-Hill Education, 2020.

[9] Barrena-Martínez, J., Cricelli, L. Ferrándiz, E., Greco, M. and Grimaldi, M. (2020). "Joint forces: towards an integration of intellectual capital theory and 
the open innovation paradigm", Journal of Business Research, vol. 112, 2020, pp. 261-270.

[10] Bartlett, C. A. and Ghoshal, S. (2017). "Managing across borders: New organizational responses", In International Business, Routledge, 2017, pp. 307-317.

[11] Belderbos, R., Lokshin, B., Boone, C. and Jacob, J. (2020). "Top management team international diversity and the performance of international R\&D", Global Strategy Journal, 2020.

[12] Bogers, M., Foss, N. J. and Lyngsie, J. (2018). "The "human side" of open innovation: The role of employee diversity in firm-level openness", Research Policy, vol. 47, no. 1, 2018, pp. 218-231.

[13] Boldizzoni, D. (2009). "Evoluzione dello Human Resource Management: dalla gestione alla valorizzazione delle Risorse Umane", La guida del Sole 24 ore al management delle risorse umane: dalla gestione del lavoratore dipendente alla valorizzazione del capitale umano, 2009, pp. 1-19.

[14] Bonache, J. and Festing, M. (2020). "Research paradigms in international human resource management: An epistemological systematisation of the field", 2020.

[15] Cooke, F. L. and Saini, D. S. (2010). "Diversity management in India: A study of organizations in different ownership forms and industrial sectors", Human Resource Management: Published in Cooperation with the School of Business Administration, The University of Michigan and in alliance with the Society of Human Resources Management, vol. 49, no. 3, 2010, pp. 477-500.

[16] Dennissen, M., Benschop, Y. and van den Brink, M. (2020). "Rethinking diversity management: an intersectional analysis of diversity networks", Organization Studies, vol. 41, no. 2, 2020, pp. 219-240.

[17] Frey, K., Lüthje, C. and Haag, S. (2011). "Whom should firms attract to open innovation platforms? The role of knowledge diversity and motivation" Long Range Planning, vol. 44, no. 5-6, 2011, pp. 397-420.

[18] Jamali, D. and Dirani, A. (2014). "Synergies of CSR and diversity management: a converging agenda", In Corporate Social Responsibility and Human Resource Management, Edward Elgar Publishing, 2014.

[19] Jolanta, M. A. J. (2015). "Diversity management's stakeholders and stakeholders management", Proceedings of the 9th International Management Conference" Management and Innovation For Competitive Advantage", Bucarest, 2015, pp. 780-793.

[20] Karataş-Özkan, M., Nicolopoulou, K. and Özbilgin M. F. (Eds.) "Corporate social responsibility and human resource management: a diversity perspective", Edward Elgar Publishing, 2014.

[21] Li H. and Chen, P. (2018). "Board gender diversity and firm performance: The moderating role of firm size", Business Ethics: A European Review, vol. 27, no. 4, 2018, pp. 294-308. 
[22] Matsa, D. A. and Miller, A. R. (2013). "A female style in corporate leadership? Evidence from quotas", American Economic Journal: Applied Economics, vol. 5, no. 3, 2013, pp. 136-69.

[23] Meena, K. and Vanka, S. (2017). "Developing an empirical typology of diversity-oriented human resource management practices", Journal of Management Development, 2017.

[24] Mullins, F. (2018). "HR on board! The implications of human resource expertise on boards of directors for diversity management", Human resource management, vol. 57, no. 5, 2018, pp. 1127-1143.

[25] Ollapally A. and Bhatnagar, J. (2009). "The holistic approach to diversity management: HR implications", Indian Journal of Industrial Relations, 2009, pp. 454-472.

[26] Rose, C. (2007). "Does female board representation influence firm performance? The Danish evidence", Corporate Governance: An International Review, vol. 15, no. 2, 2007, pp. 404-413.

[27] Sabharwal, M. (2014). "Is diversity management sufficient? Organizational inclusion to further performance", Public Personnel Management, vol. 43, no. 2, 2014, pp. 197-217.

[28] Sastre, J. F. (2015). "The impact of R\&D teams' gender diversity on innovation outputs", International Journal of Entrepreneurship and Small Business, vol. 24, no. (1), 2015, pp. 142-162.

[29] Schwartz-Ziv, M. (2012). "When All Are A-board: Does the Gender of Directors Matter?", Journal of Financial and Quantitative Analysis, forthcoming, 2012.

[30] Scroggins, W. A. and Benson, P. G. (2010). "International human resource management: diversity, issues and challenges", Personnel Review, 2010.

[31] Serio, L. (2014). "Il Diversity Management e le strategie di impresa: alcune tendenze evolutive", 2014, pp. 148-159.

[32] Smith, N., Smith, V. and Verner, M. (2006). "Do women in top management affect firm performance? A panel study of 2,500 Danish firms", International Journal of productivity and Performance management, 2006.

[33] Söllner, R. (2010)."Human capital diversity and product innovation: A microlevel analysis", Jena Economic Research Papers, 2010.

[34] Starostka-Patyk, M., Tomski, P. and Zawada, M. (2015). "Diversity management as a part of corporate social responsibility policy", Procedia Computer Science, vol. 65, 2015, pp. 1038-1045.

[35] Sukalova, V. and Ceniga, P. (2020), "Diversity Management in Sustainable Human Resources Management" SHS Web of Conferences, EDP Sciences Vol. 74, 2020, p. 01033.

[36] Sun, W., Ding, Z. and Price, J. (2020). "Board structure and firm capability: An environment-embedded relationship between board diversity and marketing capability", Industrial Marketing Management, vol. 90, 2020, pp. 14-29. 
[37] Svendsen, M. F., Haugland, S. A. (2011). K. Grønhaug and T. Hammervoll, "Marketing strategy and customer involvement in product development" European Journal of Marketing, 2011.

[38] Tatli, A. (2011). "A multi-layered exploration of the diversity management field: diversity discourses, practices and practitioners in the UK" British Journal of Management, vol. 22, no. 2, 2011, pp. 238-253.

[39] Teodósio, J., Vieira, E. and Madaleno, M. (2021). "Gender diversity and corporate risk-taking: a literature review", Managerial Finance, 2021.

[40] Torres, A. and Murray, J. (2001). "Diversity, marketing practice and organisational evolution: Implications for the management of productive evolution" Journal of Change Management, vol. 2, no. 3, 2001, pp. 229-243.

[41] Wang, M. and Kelan, E. (2013). "The gender quota and female leadership: Effects of the Norwegian gender quota on board chairs and CEOs", Journal of business ethics, vol. 117, no. 3, 2013, pp. 449-466.

[42] Yadav, S. and Lenka, U. (2020). "Diversity management: a systematic review", Equality, Diversity and Inclusion: An International Journal, 2020.

[43] Yang, Y. and Konrad, A. M. (2011). "Understanding diversity management practices: Implications of institutional theory and resource-based theory", Group \& Organization Management, vol. 36, no. 1, 2011, pp. 6-38.

[44] Zimmerman, M. A. and Brouthers, K. D. (2012). "Gender heterogeneity, entrepreneurial orientation and international diversification", International Journal of Gender and Entrepreneurship, 2012. 